\title{
Impact of a large wildfire on water-soluble organic aerosol in a major urban area: the 2009 Station Fire in Los Angeles County
}

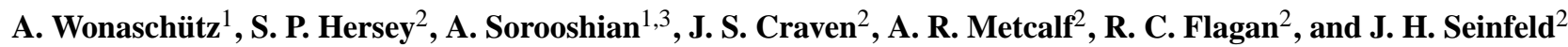 \\ ${ }^{1}$ Department of Atmospheric Sciences, University of Arizona, P.O. Box 210081, Tucson, Arizona, 85721, USA \\ ${ }^{2}$ Departments of Environmental Science and Engineering and Chemical Engineering, California Institute of Technology, 1200 \\ E. California Blvd., Pasadena, California 91125, USA \\ ${ }^{3}$ Department of Chemical and Environmental Engineering, Univ. of Arizona, P.O. Box 210011, Tucson, Arizona, 85721, USA
}

Received: 13 April 2011 - Published in Atmos. Chem. Phys. Discuss.: 27 April 2011

Revised: 24 June 2011 - Accepted: 2 August 2011 - Published: 15 August 2011

\begin{abstract}
This study examines the nature of water-soluble organic aerosol measured in Pasadena, CA, under typical conditions and under the influence of a large wildfire (the 2009 Station Fire). During non-fire periods, water-soluble organic carbon (WSOC) variability was driven by photochemical production processes and sea breeze transport, resulting in an average diurnal cycle with a maximum at 15:00 local time (up to $4.9 \mu \mathrm{g} \mathrm{C} \mathrm{m}^{-3}$ ). During the Station Fire, primary production was a key formation mechanism for WSOC. High concentrations of WSOC (up to $41 \mu \mathrm{g} \mathrm{C} \mathrm{m}^{-3}$ ) in smoke plumes advected to the site in the morning hours were tightly correlated with nitrate and chloride, numerous aerosol mass spectrometer (AMS) organic mass spectral markers, and total non-refractory organic mass. Processed residual smoke was transported to the measurement site by the sea breeze later in the day, leading to higher afternoon WSOC levels than on non-fire days. Parameters representing higher degrees of oxidation of organics, including the ratios of the organic metrics $m / z 44: m / z 57$ and $m / z 44: m / z 43$, were elevated in those air masses. Intercomparisons of relative amounts of WSOC, organics, $m / z 44$, and $m / z 43$ show that the fraction of WSOC comprising acid-oxygenates increased as a function of photochemical aging owing to the conversion of aliphatic and non-acid oxygenated organics to more acid-like organics. The contribution of water-soluble organic species to the organic mass budget (10th-90th percentile values) ranged between $27 \%-72 \%$ and $27 \%-68 \%$ during fire and non-fire periods, respectively. The seasonal incidence of wildfires in the Los Angeles Basin greatly enhances the importance of watersoluble organics, which has implications for the radiative and hygroscopic properties of the regional aerosol.
\end{abstract}

Correspondence to: A. Sorooshian (armin@email.arizona.edu)

\section{Introduction}

Organic compounds constitute roughly one half of atmospheric aerosol mass globally; this fraction can be even higher in urban areas. Between $40-85 \%$ of organic carbon measured in different locations worldwide has been shown to be water-soluble (Ruellan et al., 1999; Graham et al., 2002; Mayol-Bracero et al., 2002; Gao et al., 2003; Jaffrezo et al., 2005; Decesari et al., 2006). Water-soluble organic carbon (WSOC) species are directly emitted in primary particles, especially during biomass combustion, and produced as a result of reactions in the gas and aqueous phases (Miyazaki et al., 2006; Sullivan et al., 2006; Kondo et al., 2007; Weber et al., 2007; Ervens and Volkamer, 2010; Sorooshian et al., 2010; Timonen et al., 2010). WSOC has been suggested as a marker for secondary organic aerosol (SOA) in the absence of biomass burning (e.g. Docherty et al., 2008).

The Los Angeles Basin has been the subject of many studies examining the transport and chemical evolution of atmospheric aerosols. In Pasadena, the setting of this work, particulate pollutant concentrations are governed by numerous production and transport processes. The meteorology in the basin is characterized by early morning inversions, which, through increasing surface heating over the course of the day, give way to a robust midday-afternoon sea breeze. Elevated pollution layers can form by horizontal and vertical displacement of the morning inversion layer and orographic uplift (Lu and Turco, 1995), allowing for aerosol processing in air masses separated from surface pollution sources during the day. These pollution layers can remain aloft during the night and re-entrain the next day through turbulent mixing in a deepening boundary layer, contributing to surface concentrations of aerosols (Husar et al., 1977; Blumenthal et al., 1978).

Published by Copernicus Publications on behalf of the European Geosciences Union. 
Organic compounds are a major constituent of the local pollution and are emitted directly as well as produced via secondary processes. Hughes et al. (2000) found increasing relative contributions of organic compounds to increasing mass concentrations of total suspended particulates and fine particles due to chemical processing along a sea breeze trajectory in the Los Angeles Basin. More recent summertime measurements in the area showed that SOA is a major contributor to organic aerosol (Docherty et al., 2008), of which WSOC is an important component (Peltier et al., 2007). Owing to transport processes and spatial gradients in the oxidative capacity of the atmosphere, SOA is expected to contribute more to organic aerosol concentrations at inland areas than at the pollution source regions near the coast (Lu and Turco, 1995; Vutukuru et al., 2006).

In the late summer to fall months (August-November), following hot and dry summers, smoke from wildfires can be an additional component of the organic aerosol budget in the Los Angeles Basin (Phuleria et al., 2005). The impact of wildfires on urban aerosol physicochemical properties has been examined in other locations (Lee et al., 2008) but aerosol studies examining the superposition of biomass burning emissions and typical Los Angeles atmospheric conditions are limited. The issue is especially of interest as wildfires in the southwestern United States have been shown to occur more frequently and to last longer than only a few decades ago and are thus expected to be a major concern in a future drier and warmer climate (Westerling et al., 2006).

An opportunity to study the nature of WSOC in the Los Angeles Basin in both the presence and absence of a major fire presented itself during the 2009 Pasadena Aerosol Characterization Observatory (PACO) field campaign. The Station Fire, which began on 26 August 2009 in the Angeles National Forest and came as close as $10 \mathrm{~km}$ to the PACO field site, was the tenth largest wildfire in modern California history and the largest ever in Los Angeles County, burning an area of more than $600 \mathrm{~km}^{2}$ (California Department of Forestry and Fire Protection; http://bof.fire.ca.gov/ incidents/incidents_archived). The overall PACO campaign is described in detail by Hersey et al. (2011). Here we report an analysis of the nature of particulate WSOC in Pasadena during a three-month period with an aim towards characterizing time-dependent concentrations, relationships with other organic aerosol metrics, sensitivity to meteorology and transport, and the impact of the Station Fire. This work also provides a valuable database for comparison with subsequent field datasets collected from surface and airborne platforms during the 2010 CalNex field campaign (http://www.esrl.noaa.gov/csd/calnex/).

\section{Methods}

\subsection{Data}

During the PACO field study (May-September 2009), ground-based aerosol measurements were conducted on the roof of the Keck Building on the campus of the California Institute of Technology (Caltech). The focus of this work is the period from 6 July 2009 to 16 September 2009. WSOC in $\mathrm{PM}_{2.5}$ was measured every six minutes with a particle-intoliquid sampler (PILS; Brechtel Mfg. Inc.) coupled to a total organic carbon (TOC) analyzer (Sievers Model 800 Turbo, Boulder, CO). The instrument design and operational details are discussed extensively elsewhere (Sullivan et al., 2004). Briefly, the PILS samples particles smaller than $2.5 \mu \mathrm{m}$ in diameter and passes them through an organic carbon denuder (Sunset Laboratory Inc.) to remove organic vapors. The particles are grown into droplets, which are collected by inertial impaction. The liquid then passes through a $0.5 \mu \mathrm{m}$ PEEK (polyetheretherketone) liquid filter and is transported to a TOC analyzer for quantification of WSOC. The reported WSOC levels are the difference between the measured and background concentrations. The overall measurement uncertainty is estimated to be approximately $10 \%$.

Inorganic and non-refractory organic sub-micrometer aerosol measurements were carried out with an Aerodyne Compact Time of Flight Aerosol Mass Spectrometer (C-ToF-AMS) (Drewnick et al., 2005; Murphy et al., 2009) during the non-fire portion of the study and a HighResolution AMS (HR-AMS) during the Station Fire. AMS data used here include organic markers at specific mass-tocharge ratios $(\mathrm{m} / \mathrm{z})$ that serve as proxies for organics with a range of oxidation states: acid-like oxygenated organics $\left(\mathrm{m} / \mathrm{z}, 44=\mathrm{COO}^{+}\right)$, aliphatic and non-acid oxygenated organics $\left(m / z, 43=\mathrm{C}_{3} \mathrm{H}_{7}^{+}\right.$and $\left.\mathrm{C}_{2} \mathrm{H}_{3} \mathrm{O}^{+} ; m / z, 55=\mathrm{C}_{3} \mathrm{H}_{3} \mathrm{O}^{+}\right)$, aliphatic organics $\left(m / z 57=\mathrm{C}_{4} \mathrm{H}_{9}^{+}\right)$, and a biomass burning tracer $(m / z$ 60) (McLafferty and Turecek, 1993; Zhang et al., 2005; Aiken et al., 2008; Ng et al., 2010; Alfarra et al., 2007). The PILS and AMS chemical measurements were time synchronized, accounting for sampling time delays in the PILS relative to the AMS (Sorooshian et al., 2006). Since the PILS sampled sub-2.5 $\mu \mathrm{m}$ particles while the AMS measured submicrometer particles, ratios of WSOC to AMS data represent an upper limit.

Particle size distributions were measured with a cylindrical Scanning Differential Mobility Analyzer (DMA; TSI Model 3081) coupled to a Condensation Particle Counter (CPC, TSI Model 3760). Thirty-two days of hourly CO, $\mathrm{O}_{3}$ and $\mathrm{PM}_{2.5}$ measurements from ground sites in Pasadena (South Wilson Avenue), Upland, Burbank, and downtown Los Angeles (North Main Street) (http://www.arb.ca.gov) are used to help interpret the WSOC data. Additionally, hourly meteorological data were obtained from the Mesowest database (http://mesowest.utah.edu/index.html). The stations used include the South Wilson Avenue station on the 
Caltech campus, the North Main Street station near downtown Los Angeles $(\sim 12.5 \mathrm{~km}$ southwest of measurement site), and the Santa Fe Dam station located $\sim 15 \mathrm{~km}$ east of the measurement site.

\subsection{Fire development and influence on the measurement site}

The Station Fire burned over several weeks. Its spatial extent and exact location, and thus the influence it exerted on the measurement site, changed over that time period. Figure 1 shows the progression of the fire over several days. The fire perimeter was estimated from Moderate Resolution Imaging Spectroradiometer (MODIS) fire maps (http: //firefly.geog.umd.edu/firemap/; Justice et al., 2002; Davies et al., 2009). The fire started on 26 August less than $10 \mathrm{~km}$ north of the sampling site and grew in areal extent over the next four days. It split into an eastern and a western part on 31 August. The western part quickly decreased in size while moving northward, was reduced to a relatively small remnant $\sim 25 \mathrm{~km}$ northwest of the site by 2 September, and became unidentifiable by MODIS by 4 September. The eastern part remained sizeable, but moved farther eastward. Notable easterly wind patterns did not occur during the measurement period, making the eastern part of the fire an unlikely direct influence on the measurement site.

The dataset was split into a "fire period" and a "nonfire period" by examining the MODIS fire maps and using the AMS $m / z 60$ concentration as a tracer for biomass burning. The "fire period", consisting of the eight days between 26 August and 2 September, was marked by frequent high spikes in the measured $\mathrm{m} / \mathrm{z}, 60$ concentration, reaching values of up to $1.4 \mu \mathrm{g} \mathrm{m}^{-3}$. The mean $\mathrm{m} / \mathrm{z} 60$ concentration during the fire period was $0.065 \pm 0.122 \mu \mathrm{g} \mathrm{m}^{-3}$. During the remaining measurement days ("non-fire period") the mean $\mathrm{m} / \mathrm{z}, 60$ concentration was $0.013 \pm 0.005 \mu \mathrm{g} \mathrm{m}^{-3}$. While $m / z, 60$ (and levoglucosan) have been shown to decay with exposure to the hydroxyl radical (Hennigan et al., 2010), the systematically higher levels of this mass spectral marker during the Station Fire make it a robust tool to identify periods with fire influence. $\mathrm{CO}$ similarly exhibited contrasting behavior during non-fire and fire periods, with mean concentrations of $0.13 \pm 0.12 \mathrm{ppmv}$ and $0.45 \pm 0.50 \mathrm{ppmv}$, respectively.

\section{Results and discussion}

\subsection{PACO study background}

Hersey et al. (2011) provide a comprehensive summary of the physical and chemical properties of aerosols sampled at the PACO measurement site over the time period between 10 July and 4 August, which overlaps with the beginning of the period examined in this work. We briefly describe results from that study that are relevant to the interpretation of WSOC measurements during non-fire periods. Organic mass accounted for approximately $55 \%$ of the submicrometer AMS aerosol mass. Average organic carbon (OC) concentrations were greater by approximately $4 \%$ in the afternoons (15:00-19:00 LT) than in the mornings (07:0011:00 LT). Conversely, elemental carbon (EC) decreased by approximately $22 \%$ from the mornings to the afternoons. Both trends lead to an enhanced afternoon OC:EC ratio. It was concluded that production of primary organic carbon was more important in the mornings while secondary production of organic carbon was more dominant in the afternoons. Size-resolved measurements showed that the afternoon submicrometer organic mass distribution was bimodal with one modal vacuum aerodynamic diameter centered around 100$200 \mathrm{~nm}$ and another around $500-600 \mathrm{~nm}$. Positive matrix factorization analysis showed that low-volatility and semivolatile oxidized organic aerosol (LV-OOA and SV-OOA) accounted for $86 \%$ of organic aerosol, suggestive of a large oxidized organic fraction. This work will examine the nature and character of the water-soluble fraction of the organic aerosol.

\subsection{Meteorological setting and origin of air masses}

Weather conditions were warm and dry during the entire WSOC measurement period (Fig. 2). Ambient temperatures ranged approximately from $15^{\circ}$ to $40^{\circ} \mathrm{C}$. Relative humidity (RH) usually dropped below $40 \%$ during the day but reached $100 \%$ in the early morning hours of many days. Temperatures averaged several degrees higher during the Station Fire period, while RH was around $20 \%$ lower, helping to sustain the duration and spread of the fire. Air mass back-trajectories calculated with the NOAA HYSPLIT model (Draxler and Rolph, 2003) showed that sampled air masses were generally of marine origin with brief continental exposure prior to reaching the sampling site.

Since the western edge of the Los Angeles Basin is a major source region for pollutants (Lu and Turco, 1995), it is important to identify dominant wind patterns and transport times to Pasadena. Figure 3 shows the local wind characteristics at South Wilson Avenue (next to measurement site) and at several surrounding stations. The most common wind directions at all stations are southerly to westerly, a manifestation of the sea breeze. The diurnal development of wind at South Wilson Avenue starts with very calm air in the early mornings (and late evenings). During the late morning hours the wind tends to turn clockwise from the NE through $S$ to the predominant afternoon sea breeze direction from the SW. Wind speeds increase during the development of the sea breeze. The stagnant air in the early morning is expected to be influenced by local sources and by accumulated residual pollution from the previous day. Over the course of the late morning, air masses from more polluted urban areas are transported to Pasadena and ultimately replaced by air masses of largely 


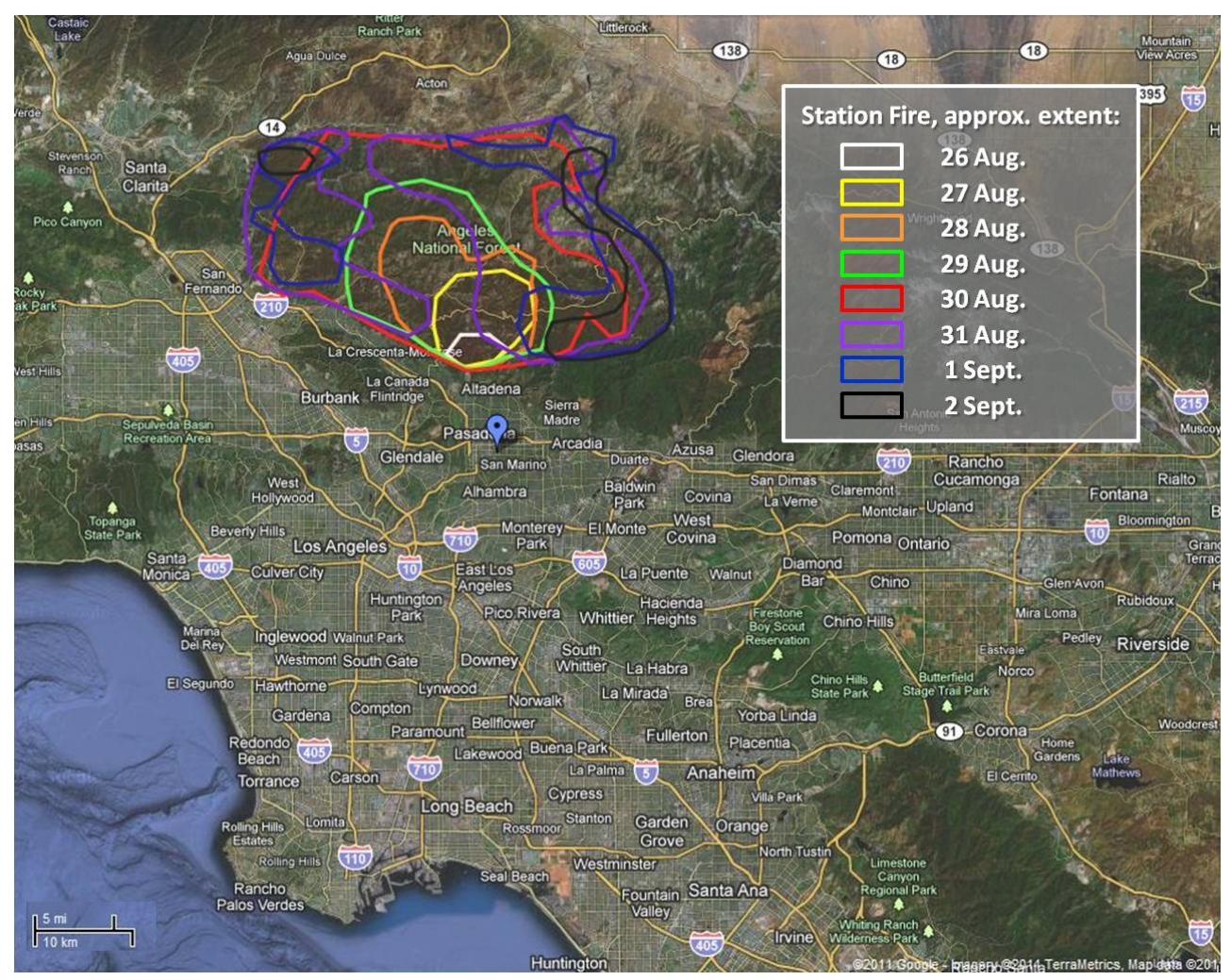

Fig. 1. Approximate spatial extent of the Station Fire by date (bordered areas). The fire area was estimated using fire maps by "Firefly" (University of Maryland; http://firefly.geog.umd.edu/firemap/). The blue marker in Pasadena represents the measurement site.

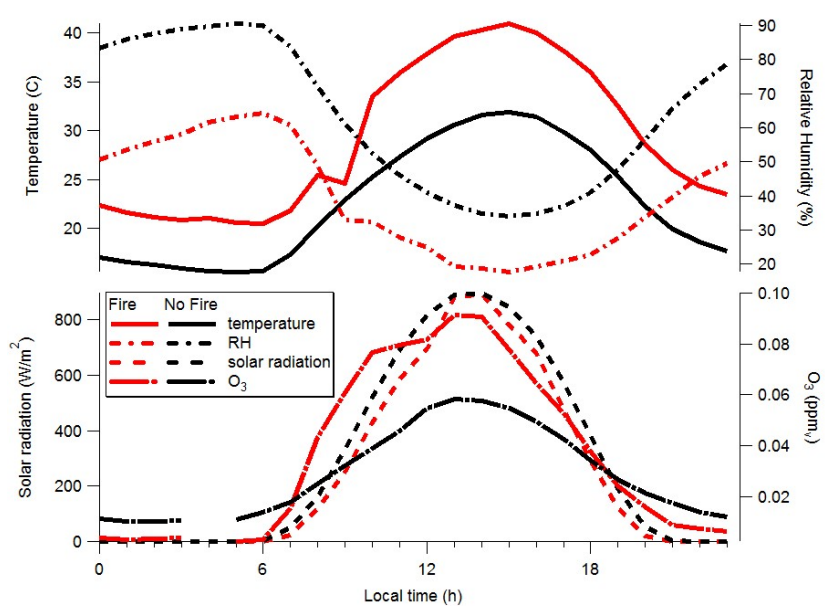

Fig. 2. Diurnal averages of meteorological parameters (Santa Fe Dam station) and $\mathrm{O}_{3}$ concentrations during the fire- and non-fire periods.

marine origin with anthropogenic influence, carrying particles with a mix of fresh and aged components. The South Wilson Avenue Station measures systematically lower wind speeds than the surrounding stations, which is likely a local effect caused by buildings and trees in the immediate surroundings of the station. Wind speeds measured at that site are therefore assumed to represent a lower limit of the areal wind speed. A statistical analysis of wind speeds and directions between 13:00-18:00 LT showed that the most common wind speeds were $4.5 \mathrm{~m} \mathrm{~s}^{-1}$ at North Main Street and $1.3 \mathrm{~m} \mathrm{~s}^{-1}$ at South Wilson Avenue. The most common wind directions were $270^{\circ}$ and $225^{\circ}$, respectively. The afternoon (13:00-18:00 LT) transport time of urban pollution from downtown Los Angeles to Pasadena is thus on the order of 1-2 h, consistent with the estimate by Hersey et al. (2011) for the period between May and August 2009. Based on the most common afternoon wind speed at North Main Street, the transport time of anthropogenically-influenced marine air from the coast to Pasadena from a southwesterly direction is approximately two hours.

\subsection{WSOC production pathways and relationship with ozone}

Identifying the relative importance of primary and secondary production mechanisms of WSOC is difficult given the large variety of aerosol and precursor sources, the diurnal transport patterns and the dynamic vertical structure of the boundary layer in the basin (Blumenthal et al., 1978; Vutukuru et al., 2006). WSOC concentrations measured on non-fire days 


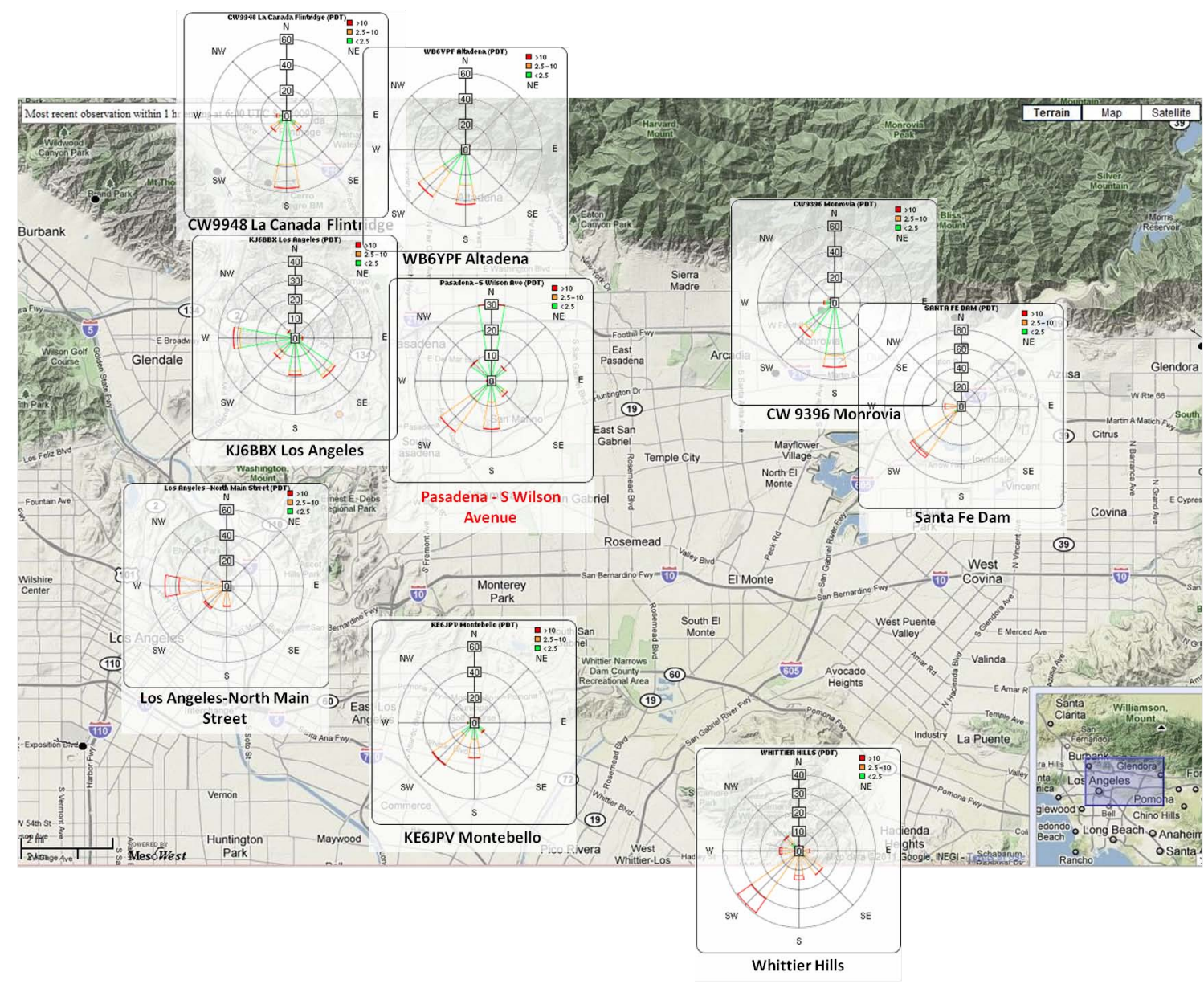

Fig. 3. Wind roses for the month of July for South Wilson Avenue and surrounding stations (data from Mesowest, http://mesowest.utah.edu/ index.html).

may be governed by all or a subset of the following mechanisms: (1) local primary production of WSOC; (2) local secondary production; (3) advection of existing WSOC that was either primarily or secondarily produced; (4) advection of precursor volatile organic compounds (VOCs), with WSOC production occurring during transport; (5) volatilization of semivolatile primary organic aerosol (POA) and subsequent oxidation into SOA (Robinson et al., 2007); and (6) re-entrainment of pollution layers aloft. The Station Fire adds another level of complexity by introducing additional sources of WSOC: direct emission and secondary production from precursors emitted in the fire.

Previous work within the PACO campaign has shown that the temporal behavior of organic aerosol is closely related to that of $\mathrm{O}_{3}$, indicative of photochemical production of SOA (Hersey et al., 2011). In this study, this relationship is explored by examining the relative temporal behavior of $\mathrm{O}_{3}$ and WSOC on 20 days. WSOC peaked after $\mathrm{O}_{3}$ on 16 of those days with a typical time lag of $1.5-2.5 \mathrm{~h}$. WSOC peaks occurred simultaneously or slightly before $\mathrm{O}_{3}$ peaks $(0.5 \mathrm{~h})$ on three days, and only on one day did the WSOC peak precede an unusually late $\mathrm{O}_{3}$ peak by hours. This points to a strong link between overall WSOC concentrations and photochemical processes.

The variability of $\mathrm{O}_{3}$ concentrations at different ground sites in the Los Angeles Basin provides insight into the spatiotemporal behavior of photochemical processes and the photochemical potential at the Pasadena site. $\mathrm{O}_{3}$ concentrations measured at ground stations in Pasadena (South Wilson Avenue), Burbank, Upland and downtown Los Angeles (North Main Street) were examined for a period of 24 days in July (Fig. S1, Supplement). In the prevailing sea breeze regime, transport of precursors from downtown Los Angeles (a classic pollutant source location) is expected to influence $\mathrm{O}_{3}$ concentrations at the measurement site. On 10 out of the examined 24 non-fire days, $\mathrm{O}_{3}$ peaked in downtown Los Angeles approximately an hour before it did in Pasadena, consistent with the transport times of $1-2 \mathrm{~h}$, given most common mid-afternoon (13:00 to $16: 00 \mathrm{LT})$ wind speeds of $1.3 \mathrm{~m} \mathrm{~s}^{-1}$ in Pasadena and $3.6 \mathrm{~m} \mathrm{~s}^{-1}$ at downtown Los Angeles. Peak $\mathrm{O}_{3}$ concentrations in Pasadena were consistently higher (22 out of 24 days) than in downtown Los Angeles, owing to 
advection of $\mathrm{O}_{3}$ from upwind locations and additional time for photochemical processing of $\mathrm{O}_{3}$ precursors during transport. The farther downwind site of Upland is characterized by even higher and more delayed $\mathrm{O}_{3}$ peaks. This observed spatial $\mathrm{O}_{3}$ behavior and its implications for SOA production are consistent with the findings of Vutukuru et al. (2006) who showed that SOA levels in the basin are higher at inland sites (e.g. Azusa, Riverside) than at coastal sites. However, on six days $\mathrm{O}_{3}$ reached peak concentrations in Pasadena before it did in downtown Los Angeles (an average of $1.5 \mathrm{~h}$ earlier) and on six other days, it peaked within the same hour as in downtown Los Angeles. These days were not associated with unusual wind directions or increased wind speeds. Local sources, downward mixing of elevated pollution layers from previous days in a deepening mixed layer, and/or unusually vigorous photochemical activity (as described by Hersey et al., 2011) could explain these "early" $\mathrm{O}_{3}$ peaks. Therefore, on any given day, advection of oxidants from downtown Los Angeles is not necessarily a requirement for photochemical activity in Pasadena.

\subsection{Cumulative WSOC statistics}

During the non-fire period, the highest WSOC concentration measured was $4.9 \mu \mathrm{g} \mathrm{C} \mathrm{m}^{-3}$. The observed concentration range is consistent with that of independent measurements in other urban areas (Jaffrezo et al., 2005; Sullivan et al., 2004, 2006; Kondo et al., 2007), including those in nearby Riverside during the summer of 2005 (Peltier et al., 2007). WSOC exhibits a weak correlation with solar radiation $\left(r^{2}=0.28\right)$ and somewhat higher correlations with $\mathrm{O}_{3}\left(r^{2}=0.35\right)$ and $T\left(r^{2}=0.44\right)$ (Table 1). The highest correlations between WSOC and AMS aerosol components were found for the following organic markers: $m / z 43\left(r^{2}=0.49\right)$, total AMS organic mass $\left(r^{2}=0.47\right)$, and $\mathrm{m} / z 55$ and $60\left(r^{2}=0.45\right)$. The correlation of WSOC with $\mathrm{m} / z 57\left(r^{2}=0.20\right)$ is the lowest among the correlations with AMS organic markers. Although $\mathrm{m} / \mathrm{z}, 55$ and $\mathrm{m} / \mathrm{z}, 43$ are prominent components in traffic emissions, they are more related to oxygenated organics than the primary hydrocarbon-like organic aerosol (HOA) marker $m / z 57$ (e.g. Zhang et al., 2005); for example, they are in general less correlated with $\mathrm{NO}_{\mathrm{x}}$ and $\mathrm{CO}$. WSOC exhibits little to no correlation with the inorganic compounds nitrate $\left(\mathrm{NO}_{3}^{-}\right)$, sulfate $\left(\mathrm{SO}_{4}^{2-}\right)$, chloride $\left(\mathrm{Cl}^{-}\right)$, and ammonium $\left(\mathrm{NH}_{4}^{+}\right)\left(r^{2} \leq 0.08\right)$.

During the fire period, the range of measured WSOC levels $\left(0.8-40.6 \mu \mathrm{g} \mathrm{C} \mathrm{m}^{-3}\right)$ was consistent with that observed in other measurements with major biomass burning influence: $11-46 \mu \mathrm{g} \mathrm{C} \mathrm{m}^{-3}$ (Mayol-Bracero et al., 2002), 2.2$39.6 \mu \mathrm{g} \mathrm{C} \mathrm{m}^{-3}$ (Graham et al., 2002), $4.4-52.6 \mu \mathrm{g} \mathrm{m}^{-3}$ (Decesari et al., 2006), and 0.57-18.45 $\mu \mathrm{g} \mathrm{C} \mathrm{m}^{-3}$ (Sullivan et al., 2006). The highest WSOC concentration, $40.6 \mu \mathrm{g} \mathrm{C} \mathrm{m}{ }^{-3}$, was measured in the morning of 30 August. WSOC correlations $\left(r^{2}\right)$ with most organic metrics (i.e. total AMS organic mass and $m / z, 44,60,43$, and 55 , but not $m / z 57$ ) ranged between 0.80 and 0.92 (cf. 0.35 and 0.49 during non-fire periods). The systematically higher correlations during the fire period indicate that there was a dominant factor governing the variability of both organic and WSOC levels; since WSOC was highly correlated with $m / z 60\left(r^{2}=0.90\right)$, the fire emissions were clearly influential. The correlation of WSOC with $\mathrm{O}_{3}$ is absent during the fire period, even though $\mathrm{O}_{3}$ concentrations are influenced by the fire (peak concentrations in the diurnal average of $91.5 \mathrm{ppbv}$ during the fire vs. $58.5 \mathrm{ppbv}$ for the non-fire diurnal average; Fig. 2). This suggests that photochemical production is not the dominant process governing the large variability of WSOC concentrations during the fire. A high correlation was observed between WSOC and both $\mathrm{NO}_{3}^{-}\left(r^{2}=0.79\right)$ and $\mathrm{Cl}^{-}\left(r^{2}=0.57\right)$. Correlations with $\mathrm{NH}_{4}^{+}$and $\mathrm{SO}_{4}^{2-}\left(r^{2} \leq 0.18\right)$ were poor. Fresh biomass burning emissions consist mainly of organic carbonaceous components and have been reported to have only minor contributions from inorganic species (Reid et al., 2005; Fuzzi et al., 2007; Grieshop et al., 2009); however, enhanced $\mathrm{NO}_{3}^{-}$ concentrations have been observed in smoke plumes (Gao et al., 2003; Reid et al., 2005; Peltier et al., 2007). Potassium chloride is also thought to be a common constituent in biomass burning emissions (Posfai et al., 2003; Reid et al., 2005), which can explain the enhanced correlation of WSOC and $\mathrm{Cl}^{-}$and provides support for a primary WSOC production mechanism. Reid et al. (2005) note that while $\mathrm{SO}_{4}^{2-}$ is a secondary product of biomass burning, its production requires high RH. Enhanced RH also increases WSOC partitioning to the aerosol phase (Hennigan et al., 2008, 2009). However, ambient RH was low during the majority of the PACO study and especially low during the fire (Fig. 2). Liquid-phase production of $\mathrm{SO}_{4}^{2-}$ and organics could conceivably have taken place in pyrocumulus clouds formed by the fire, but given the lack of observed $\mathrm{SO}_{4}^{2-}$ at the sampling site during smoke events and the low $\mathrm{RH}$, it is unlikely that multi-phase processes played a key role in influencing surface WSOC levels.

During the fire period, the ratio of WSOC to organic mass ranged from 0.11 to $0.53 \mu \mathrm{g} \mathrm{C}_{\mu \mathrm{g}}-1$, with a 10 th percentile of 0.15 and a 90th percentile of $0.40 \mu \mathrm{g} \mathrm{C} \mu \mathrm{g}^{-1}$. After converting the 10th and 90th percentile values to an equivalent organic mass concentration using a factor of 1.8 (Docherty et al., 2008), water soluble organics are estimated to account for between $27 \%$ and $72 \%$ (with an average of $47 \% \pm 15 \%$ ) of the organic mass. The WSOC:organic ratio range during the non-fire period is similar $\left(10\right.$ th $/ 90$ th $\left.=0.15 / 0.38 \mu \mathrm{g} \mathrm{C}_{\mu \mathrm{g}}{ }^{-1}\right)$.After applying the 1.8 conversion factor to WSOC the 10th-90th percentile range is $27 \%-68 \%$ (average of $45 \% \pm 16 \%$ ). 
Table 1. Summary of the statistical relationships between WSOC $\left(\mu \mathrm{g} \mathrm{Cm}^{-3}\right)$ and other chemical and meteorological parameters (meteorological data from the Santa Fe Dam station).

\begin{tabular}{|c|c|c|c|c|c|c|c|c|c|}
\hline & & \multicolumn{4}{|c|}{ Station Fire } & \multicolumn{4}{|c|}{ No Fire } \\
\hline & & $r^{2}$ & Slope & Intercept & $n$ & $r^{2}$ & Slope & Intercept & $n$ \\
\hline \multirow{10}{*}{$\begin{array}{l}\text { AMS } \\
\left(\mu \mathrm{g} \mathrm{m}^{-3}\right)\end{array}$} & Total organic & 0.92 & -1.05 & 0.34 & 1298 & 0.47 & 0.14 & 0.69 & 1557 \\
\hline & $m / z 60$ & 0.90 & 40.16 & 1.88 & 1298 & 0.45 & 94.46 & 0.48 & 1557 \\
\hline & $m / z 44$ & 0.84 & 3.04 & -1.15 & 1298 & 0.35 & 0.95 & 0.94 & 1557 \\
\hline & $m / z 43$ & 0.84 & 5.22 & -1.45 & 1298 & 0.49 & 2.25 & 0.51 & 1557 \\
\hline & $m / z 55$ & 0.80 & 9.47 & -1.43 & 1298 & 0.45 & 3.79 & 0.61 & 1557 \\
\hline & $\mathrm{NO}_{3}^{-}$ & 0.79 & 4.30 & -1.09 & 1298 & 0.00 & -0.02 & 1.75 & 1557 \\
\hline & $\mathrm{Cl}^{-}$ & 0.57 & 77.39 & 0.99 & 1296 & 0.03 & -1.28 & 1.82 & 1557 \\
\hline & $m / z, 57$ & 0.47 & 1.24 & 0.60 & 1298 & 0.20 & 6.58 & 0.96 & 1557 \\
\hline & $\mathrm{NH}_{4}^{+}$ & 0.18 & 7.06 & 0.54 & 1298 & 0.00 & 0.04 & 1.64 & 1557 \\
\hline & $\mathrm{SO}_{4}^{2-}$ & 0.14 & -2.67 & 7.41 & 1298 & 0.08 & 0.14 & 1.40 & 1557 \\
\hline \multirow[t]{3}{*}{ Gas } & $\mathrm{CO}$ (ppmv) & 0.18 & 3.66 & 2.78 & 151 & 0.00 & 0.26 & 1.69 & 212 \\
\hline & $\mathrm{O}_{3}$ (ppbv) & 0.05 & 0.03 & 3.35 & 151 & 0.35 & 0.02 & 0.83 & 212 \\
\hline & $\mathrm{NO}_{\mathrm{x}}(\mathrm{ppbv})$ & -0.01 & -0.01 & 4.77 & 151 & 0.03 & -0.01 & 1.94 & 212 \\
\hline \multirow[t]{4}{*}{ Meteorology } & Wind speed $\left(\mathrm{m} \mathrm{s}^{-1}\right)$ & 0.07 & - & - & 144 & 0.11 & - & - & 210 \\
\hline & Solar radiation $\left(\mathrm{W} \mathrm{m}^{-2}\right)$ & 0.00 & - & - & 148 & 0.28 & - & - & 209 \\
\hline & $T(\mathrm{C})$ & 0.01 & - & - & 144 & 0.44 & - & - & 209 \\
\hline & $\mathrm{RH}(\%)$ & 0.00 & - & - & 147 & 0.14 & - & - & 209 \\
\hline
\end{tabular}

\subsection{Diurnal WSOC behavior}

\subsubsection{Non-fire period}

During the non-fire period, the daytime diurnal average concentration of WSOC (Fig. 4) exhibits a maximum at 15:00 LT, around the same time as maxima in AMS organic mass, $m / z$, 44 and $m / z, 43$, but after $\mathrm{O}_{3}$ (13:00 LT) and solar radiation (14:00 LT) (Fig. 2). Since wind direction has a pronounced diurnal cycle, too, the afternoon peak in WSOC can be explained plausibly by both photochemical production and/or transport from downtown Los Angeles via the afternoon sea breeze (a complication in explaining diurnal variability of pollutants noted specifically for Pasadena by Blumenthal et al., 1978). The behavior of the HOA marker $\mathrm{m} / z, 57$ provides some insight: while it does show an increase starting at 06:00 and a local peak at 09:00, consistent with local rush hour traffic, its maximum concentration occurs at 13:00, when local primary emissions are expected to be lower than in the morning. Since all other organic metrics and total AMS mass also reach their highest concentrations with high temporal coincidence in the early afternoon, it is likely that transport from more polluted areas, including downtown Los Angeles, plays the dominant role. From the peak at 15:00 until the evening hours, WSOC concentrations decrease, as do other organic metrics and total AMS mass. While dilution as a result of a deepening boundary layer can be a mechanism for daytime concentration decreases, the late onset of the decrease suggests that it is caused by the sea breeze: After initially transporting pollutants from source areas to Pasadena, the continuing onshore winds advect cleaner marine air. This advancing sea breeze front has been shown to produce strong gradients in pollutant concentrations in the Los Angeles Basin (Lu and Turco, 1995).

Transport does not explain all features of diurnal WSOC behavior. Even when it dominates the observed concentration variability at the measurement site, it is possible that the WSOC was secondarily produced upwind or during transport. In the diurnal average, WSOC concentrations (and $\mathrm{m} / \mathrm{z}$ 44) do not show as steep of a decrease as organics and total AMS mass (Fig. 4). The ratio WSOC:organic (Fig. 5) is relatively constant until 14:00, but then begins to increase. A likely scenario for the relative increase of WSOC during the decrease of absolute concentrations of most every organic marker is the superposition of secondary production of WSOC by photochemical processing and transport. Advected marine air may exhibit enhanced WSOC:organic ratios and, in addition, the organic aerosol advected by the sea breeze ages and oxidizes while moving inland.

Examples for these mechanisms governing WSOC concentrations on individual days can be seen in the time series in Fig. 6. On 7 July, sea breeze transport was dominant: there is strong covariance between WSOC, AMS organic mass and numerous $m / z$ markers $(43,44,55,57,60)$. All exhibit a 


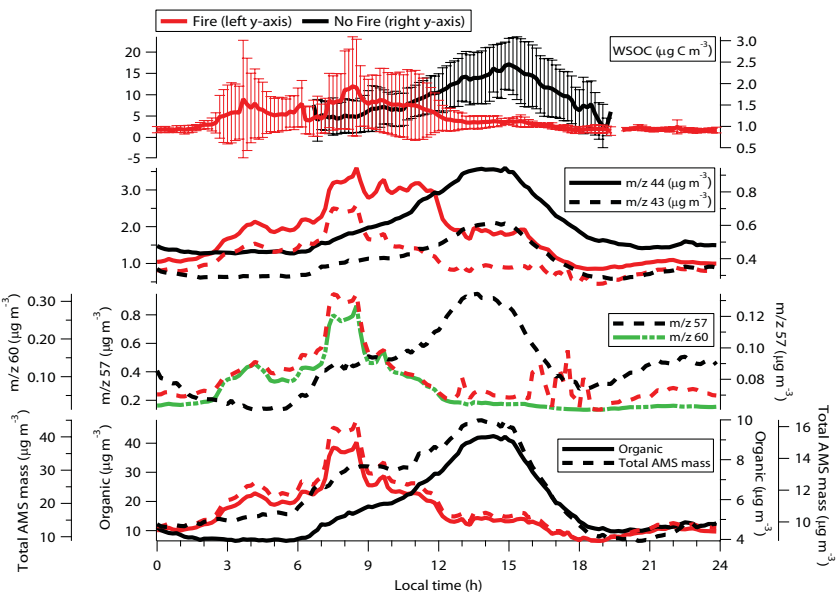

Fig. 4. Diurnal averages of aerosol chemistry $(\mathrm{m} / \mathrm{z} 60$ shown for the fire period only).

smooth morning increase followed by an equally smooth afternoon decrease which coincides with increasing afternoon wind speeds and southerly to southwesterly wind direction. The ratio of WSOC:total AMS mass shows the same behavior, likely due to photochemical processing of the transported air. The afternoon increase in $\mathrm{SO}_{4}^{2-}$ coupled with the decrease of organics can be attributed to the influx of marine air. On 11 and 15 July, in contrast, WSOC concentrations began to increase before the sea breeze was fully established, indicating that local photochemical production may have played a more important role.

\subsubsection{Station Fire period}

During the fire period, organic mass fractions (organics:total AMS mass) were substantially higher than in the non-fire period (Fig. 5). The contribution of WSOC to organic mass was systematically elevated from the early morning hours through the late afternoon, with higher WSOC:organic ratios between 04:00-12:00 than at other times. Absolute WSOC concentrations peaked in the mornings. For 08:30 in the morning, the average WSOC concentration (Fig. 4) is higher by a factor of 10 than the non-fire average for the same time of day. The diurnal behavior of the biomass burning tracer $m / z, 60$ matches that of WSOC (with the exception of a sharper decrease from 08:00 to 12:00), providing evidence for the presence of biomass burning aerosols at the measurement site when WSOC increased in concentration. Boundary layer deepening over the course of the late morning and the onset of the sea breeze with its southwesterly winds directing smoke plumes away from the measurement site lead to a decrease in measured WSOC concentrations during the rest of the day. The afternoon peak of diurnally-averaged WSOC at 15:00 that was evident during the non-fire period is barely visible given the high WSOC concentrations during earlier parts of the days; nonetheless, the diurnally-averaged WSOC

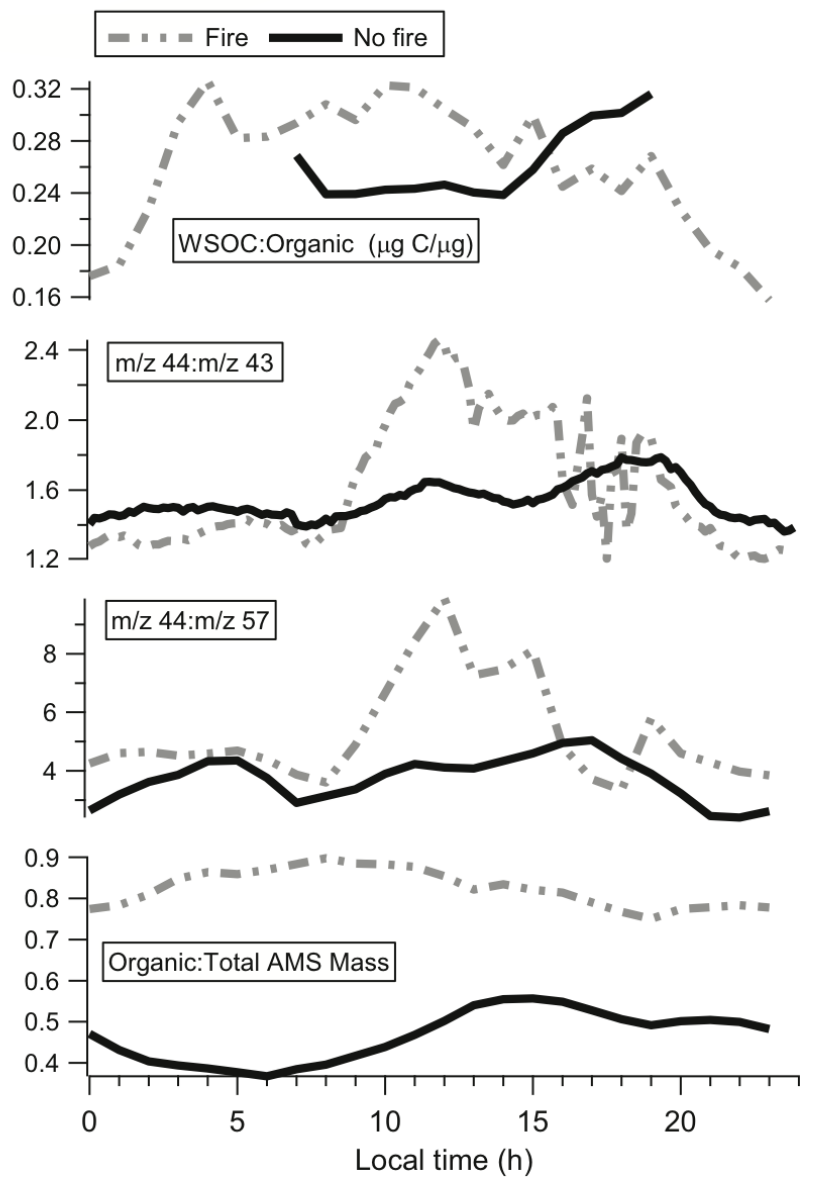

Fig. 5. Diurnally averaged ratios of different organic aerosol measurements during the fire and non-fire periods.

concentration at this time of day exceeds that of the non-fire period by a factor of 1.5. As organic precursors emitted in the fire were likely present in the entire Los Angeles Basin after several days of burning, residual and processed smoke are thought to have played an additional role in the usual transport of pollutants by the afternoon sea breeze.

Day-to-day variability of WSOC concentrations and other aerosol constituents was high during the fire period (Fig. 7). The impact of the fire on the measurement site ranged from large increases of every measured quantity on 28,30 and 31 August, to much reduced fire influence on 29 August and 1 September. This can be attributed to the dynamic development of the fire itself, as well as effects associated with wind and boundary layer depth. The connection between wind and smoke influence on aerosol composition is clearly visible in Fig. 7: using $m / z 60$ as a tracer for the smoke plume, it is evident that periods with low wind speeds and wind directions with a northerly component feature the highest smoke concentrations. Concentrations are higher in the morning hours than in the evenings (when wind speeds are equally low) because the boundary layer is shallowest in the morning and 

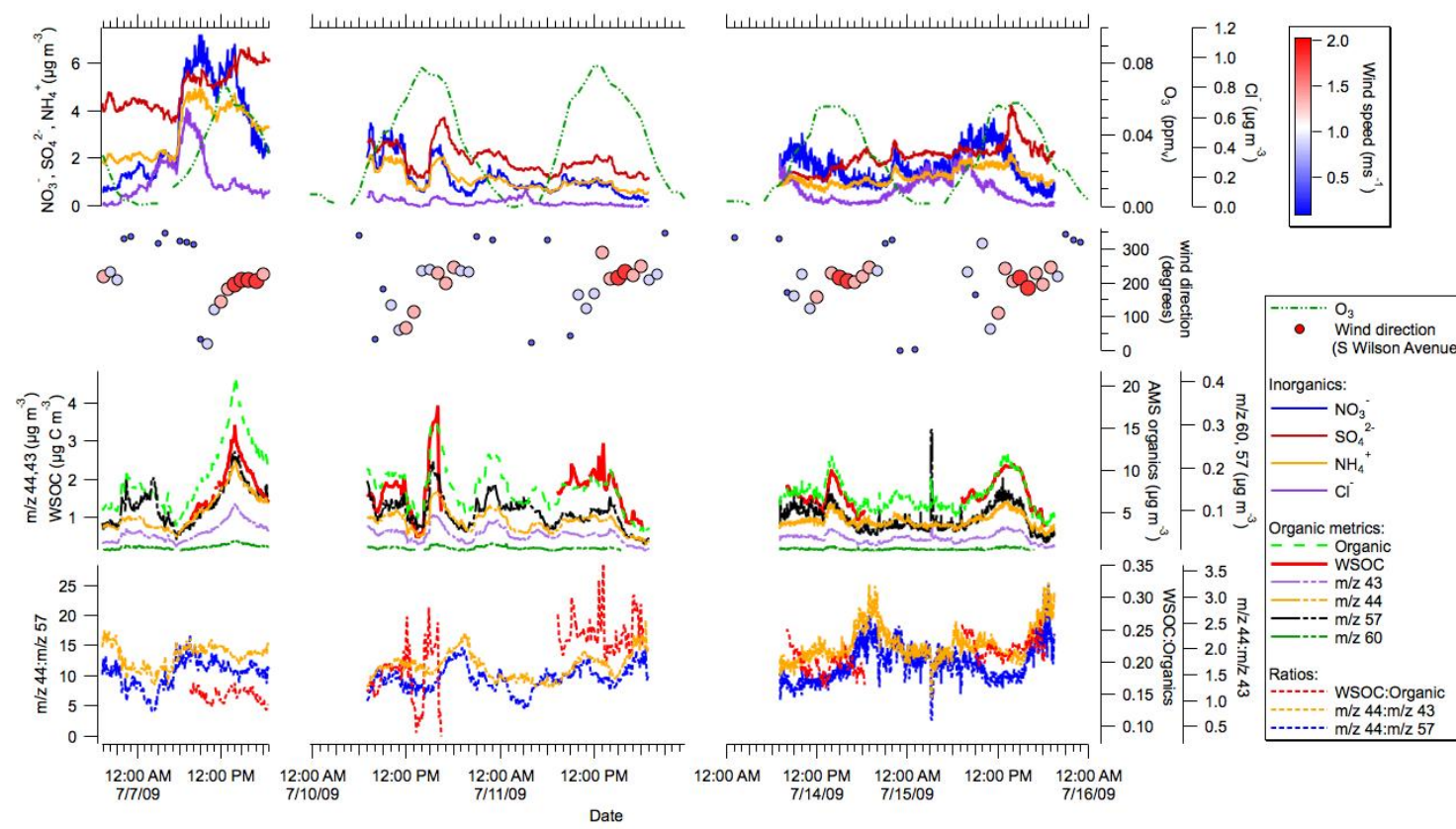

Fig. 6. Time series of various measured and derived parameters during selected days outside the fire period. The symbol size for wind direction is proportional to measured wind speed (South Wilson Avenue station).

the smoke has had time to accumulate in stagnant conditions. Concentrations of $\mathrm{m} / \mathrm{z} 60$ decrease immediately as the wind direction shifts and the wind speed picks up in the developing sea breeze. During the heavily smoke-impacted mornings of 28, 30 and 31 August, WSOC shows a very tight correlation with $m / z 60, \mathrm{NO}_{3}^{-}$, and $\mathrm{Cl}^{-}$, suggestive of primary production of WSOC in the fire. Most other AMS measurements also vary in lockstep with WSOC, with the notable exception of $\mathrm{SO}_{4}^{2-}$, which exhibited a poor correlation with WSOC and lower levels in the diurnal average than on non-fire days.

In the afternoons of 28, 30 and 31 August, WSOC concentrations were about a factor of two higher than the non-fire average. Concentrations of $\mathrm{m} / \mathrm{z}$ 60, while having dropped since the morning, were still elevated by a factor of two to three above average non-fire concentrations, an indicator that smoke distributed all over the Los Angeles Basin. CO Measurements from ground stations (Fig. S1, Supplement) were used to confirm this wider impact of the fire: on 30 and 31 August, CO levels in downtown Los Angeles exceeded typical rush hour values by a factor of two to three showing that the fire had a direct influence on locations farther south and southwest of Pasadena. Thus, even when the afternoon sea breeze directed the smoke plume away from the site, it still transported residual smoke to the site. This residual smoke was subject to photochemical processing: Fig. 5 shows large systematic increases in the ratios $\mathrm{m} / \mathrm{z} 44: 43$ and $\mathrm{m} / \mathrm{z}$ 44:57 between 09:00-15:00 while the absolute values of all organic measurements decreased (cf. Fig. 4). The larger increases of these ratios during the fire compared to non-fire conditions point to a more vigorous conversion of organics towards a more oxidized state at a relatively stable WSOC:organic ratio. Diurnal average $\mathrm{O}_{3}$ concentrations (Fig. 2) exhibit an earlier rise and a higher maximum than during the non-fire period, underlining the impact of the fire on the timing and magnitude of photochemical activity. The afternoon increases of $m / z, 44: 57$ and $m / z, 44: 43$ and the unusually high $\mathrm{O}_{3}$ concentrations ( $176 \mathrm{ppbv}$ at $14: 00$ on $30 \mathrm{Au}-$ gust and $124 \mathrm{ppbv}$ at 10:00 on 31 August) are also clearly visible in the time series for individual days (Fig. 7). Size distribution data (Fig. S2, Supplement) show that the smoke events in the morning hours are associated with larger particles (modal diameter of about $150 \mathrm{~nm}$ ) than typically observed during that time on non-fire days (modal diameter of $80 \mathrm{~nm}$ ). In the afternoon, there is a distinct shift to smaller particles (around $40 \mathrm{~nm}$ ) with a maximum concentration at approximately 15:00, coinciding with an increase in WSOC concentrations owing most likely to photochemical production.

\subsection{Relationships between WSOC, AMS organic, $m / z 44$, and $m / z 43$}

Primary emission in a fire is a very different source of WSOC than photochemical processing of precursor pollutants. The chemical nature of the WSOC measured in the morning smoke-plumes is therefore expected to differ from that measured in the afternoons. Since WSOC contains both hydrophobic and hydrophilic fractions (e.g. Sullivan and Weber, 2006), it is of interest to investigate the relative behavior 


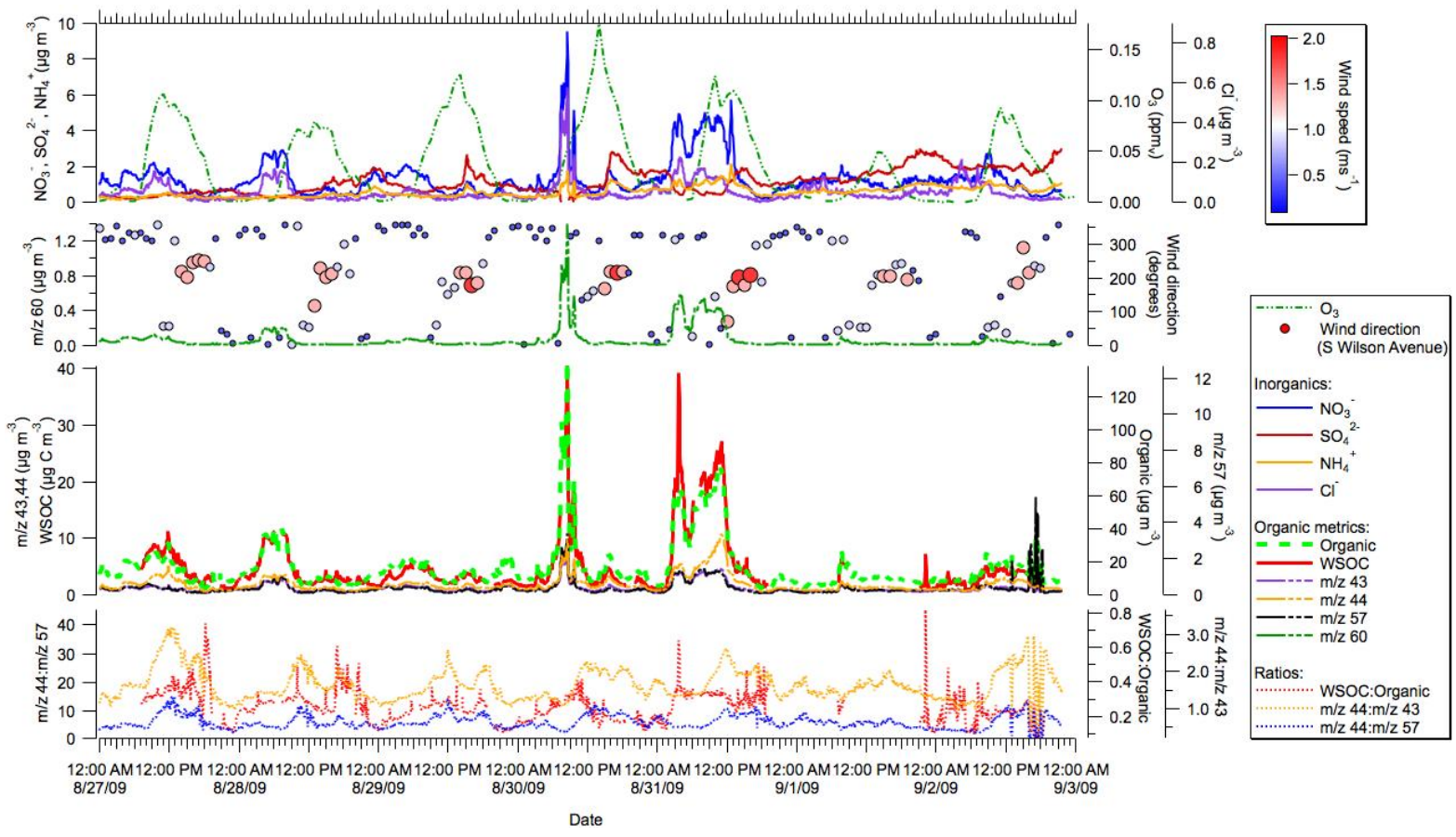

Fig. 7. Time series of various measured and derived parameters during the Station Fire period. The symbol size for wind direction is proportional to measured wind speed (South Wilson Avenue station).

of $m / z 44, m / z 43$, total AMS organic, and WSOC. Fire period morning-to-afternoon ratios (i.e. concentrations at 08:00 versus 14:00) of diurnally-averaged $\mathrm{m} / \mathrm{z} 44,43,60$, organic, and WSOC concentrations (shown in Fig. 4) were examined. The smallest morning-to-afternoon ratio for any of these organic metrics was found for $m / z, 44$ (1.9), followed by AMS organic (2.4), $m / z, 43$ (2.7), and WSOC (3.3). The morningto-afternoon ratio for $m / z 60$ was 9.6 , confirming the much larger direct influence of the fire in the morning. Given the different morning-to-afternoon ratios of $m / z, 44$ and 43 , it is plausible that the afternoon WSOC contained constituents produced as a result of photochemical processing of smoke, with more of the non-acid oxygenates having been converted to acid-like oxygenates.

Recent studies have utilized $\mathrm{m} / \mathrm{z}, 44$ and $\mathrm{m} / \mathrm{z} 43$ (Ng et al., 2010; Chhabra et al., 2011) to track the aging of organic aerosols in the atmosphere. For the PACO campaign, Hersey et al. (2011) conducted an analysis of $f_{44}(\mathrm{~m} / \mathrm{z}$ 44:total organic signal) versus $f_{43}(\mathrm{~m} / \mathrm{z}$ 43:total organic signal), where higher levels of $f_{44}$ relative to $f_{43}$ are thought to indicate a greater degree of organic oxygenation and lower volatility. Over the span of four months, they observed a high level of consistency in the overall degree of oxidation of the aerosol over a span of several months. Ng et al. (2010) conduct a related type of analysis (see their Fig. 5), suitable for incorporating measurements from instruments other than the AMS: plotting $f_{44}$ and the O:C ratio versus $m / z, 44: 43$, they observed that both $f_{44}$ and the O:C ratio increase sharply at the beginning of oxidation and then plateau at larger $\mathrm{m} / \mathrm{z}$ 44:43 ratios, suggesting the existence of a maximum oxidation state of the aerosol. Following a similar approach, we examine the ratio of $\mathrm{m} / \mathrm{z} 44$ :WSOC as a function of the $m / z$ 44:43 ratio for both the fire- and non-fire period (Fig. 8). The $m / z$ 44:43 ratios range between 0.6-2.7 (non-fire period) and 1.1-3.1 (fire period). In the mentioned plot in $\mathrm{Ng}$ et al. (2010, Fig. 5), this is a range in which the O:C ratio and $f_{44}$ are increasing rapidly prior to reaching a plateau. During both the fire-and the non-fire period, the ratio $m / z$ 44:WSOC grows as a function of $m / z$ 44:43, indicating that the contribution of acid-like oxygenates to WSOC increases as the chemical functionality of the species contributing to $\mathrm{m} / \mathrm{z} 44$ and 43 moves towards a more oxidized state. This is most clearly illustrated by the data representing the greatest influence by the fire (larger symbols in Fig. 8). The early morning smoke plumes advected to the measurement site exhibit relatively low values of $m / z$ 44:43. The $m / z$ 44:WSOC ratio increases gradually as a function of $\mathrm{m} / z, 44: 43$ and time of day, suggesting that conditions associated with transitioning from morning to afternoon hours (higher temperatures, $\mathrm{O}_{3}$, solar radiation) promoted processing of organics to contain more oxidized species and of WSOC to contain more acidlike oxygenates. 


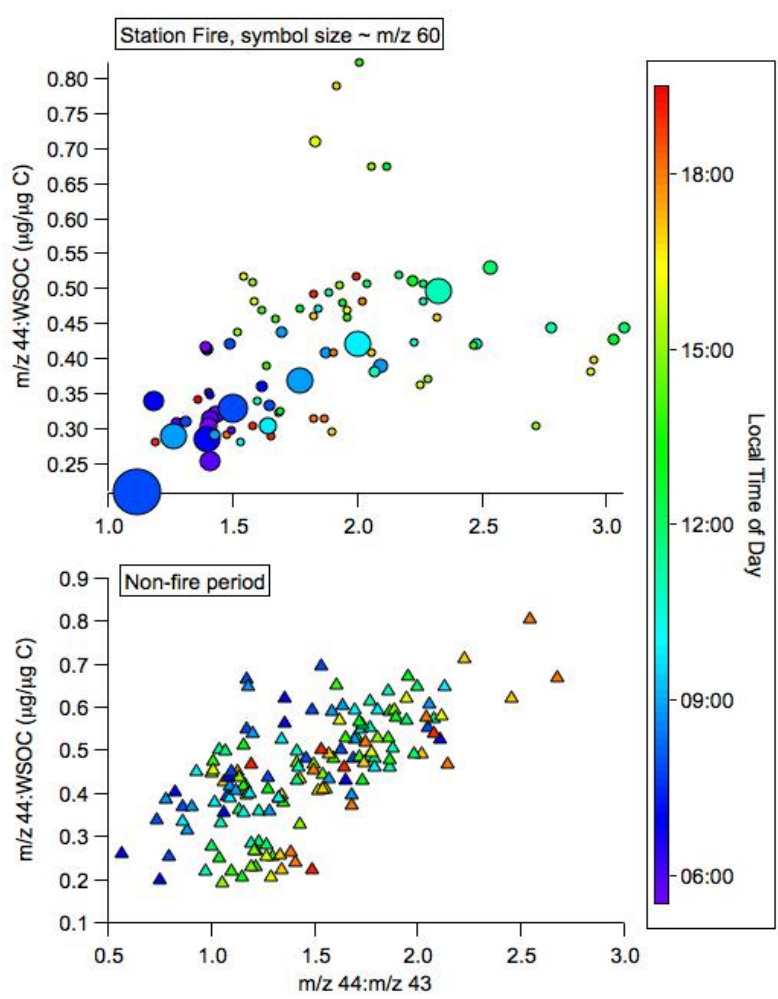

Fig. 8. Summary of the ratio $\mathrm{m} / \mathrm{z} 44$ :WSOC as a function of $\mathrm{m} / \mathrm{z}$ 44:43 during (top panel) and outside (bottom panel) the Station Fire period. Symbols are color-coded by time of day, and in the Station Fire panel the symbol size is proportional to the tracer for biomass burning, $m / z, 60$ (range $\left.=0.03-0.9 \mu \mathrm{g} \mathrm{m}^{-3}\right)$.

\section{Conclusions}

This work examines a ground-based field dataset of WSOC in conjunction with numerous other aerosol, gas, and meteorological measurements. Two periods governed by the presence and absence of a major wildfire are separately examined with respect to WSOC and the processes governing its temporal variability at a fixed site in Pasadena, California. The PACO study showed that in the absence of biomass burning, changes in WSOC concentrations in Pasadena are largely driven by the diurnal sea breeze circulation and concurrent photooxidation of the transported airmasses. Initially, in the early afternoon, the sea breeze transports pollutants from the direction of the source-rich western Los Angeles area to Pasadena. Chemical processing of those air masses likely occurs while they are on their way and contributes to the temporal WSOC concentration gradient observed at the measurement site, in addition to the influx of WSOC that was already produced at upwind locations. Later in the afternoons, the continuing sea breeze brings in cleaner air masses. These processes cause a marked decrease in WSOC, but enhanced WSOC:organic ratios. Given our observations, photochemical processes are important for overall WSOC forma- tion in the Los Angeles Basin, but cannot be assumed to dominate the observed variability at a single site. That variability is determined by a combination of transport and secondary formation processes, as well as factors we were unable to quantify, such as the magnitude of residual WSOC levels in upwind areas and in layers aloft that may be re-entrained into a deepening boundary layer over the course of the day.

During the Station Fire, WSOC concentrations and their contributions to total organic mass were substantially higher than on typical non-fire days. WSOC was produced via both primary and secondary pathways. Close covariance of WSOC with many other measured species (nitrate, chloride, total AMS organic aerosol mass) in smoke events (defined by unusually high $\mathrm{m} / \mathrm{z} 60$ concentrations in stagnant/northerly wind conditions) is a good indicator for primary (and potentially sufficiently fast secondary) production of WSOC in the fire emissions. Secondary production of WSOC becomes detectable after the initial morning smoke plumes are directed away from the sampling site and aged smoke from farther upwind makes its way back to the measurement site with the afternoon sea breeze. Increasing $\mathrm{m} / \mathrm{z}$ 44:57 and $\mathrm{m} / \mathrm{z}$ 44:43 ratios show the ongoing oxidation of the smoke-influenced air masses once they arrive back at the measurement site. Unusually high and early $\mathrm{O}_{3}$ concentration maxima indicate high photochemical activity, which may contribute to the increased WSOC concentrations observed outside of the direct smoke plume. Multiphase processes were not a dominant source of WSOC owing to low relative humidities during the majority of the observation period.

A close examination of the relationship between WSOC, $\mathrm{m} / \mathrm{z} 44$, and $\mathrm{m} / \mathrm{z}, 3$ provided insight into the contribution of various classes of oxygenated species to WSOC as a result of aerosol aging. The ratio of $\mathrm{m} / \mathrm{z} 44$ :WSOC increased as a function of $m / z, 44: 43$ both during the fire- and the nonfire period, suggesting that non-acid oxygenates were being converted to more acidic oxygenates, thereby enhancing the contribution of the latter to WSOC.

This work has illustrated the complexity of factors governing WSOC levels at a fixed point in the Los Angeles Basin. A follow-up study using aircraft observations in the same region during the 2010 CalNex field campaign will extend the discussion of the relative importance of various factors (e.g. transport, meteorology, diverse sources) in governing concentrations and spatiotemporal variability in WSOC in this metropolitan center and outflow regions (Duong et al., 2011).

\section{Supplementary material related to this article is available online at: http://www.atmos-chem-phys.net/11/8257/2011/ acp-11-8257-2011-supplement.pdf.}


Acknowledgements. This work was supported by the Electric Power Research Institute. The authors gratefully acknowledge the NOAA Air Resources Laboratory (ARL) for provision of the HYSPLIT transport and dispersion model. We thank the governmental agencies, commercial firms, and educational institutions participating in MesoWest for providing the meteorological station data and the California EPA Air Resources Board for the access to the measurements of gaseous pollutants. We also acknowledge NASA for the production of the data used in this research effort.

Edited by: A. Nenes

\section{References}

Aiken, A. C., Decarlo, P. F., Kroll, J. H., Worsnop, D. R., Huffman, J. A., Docherty, K. S., Ulbrich, I. M., Mohr, C., Kimmel, J. R., Sueper, D., Sun, Y., Zhang, Q., Trimborn, A., Northway, M., Ziemann, P. J., Canagaratna, M. R., Onasch, T. B., Alfarra, M. R., Prevot, A. S. H., Dommen, J., Duplissy, J., Metzger, A., Baltensperger, U., and Jimenez, J. L.: O/C and OM/OC ratios of primary, secondary, and ambient organic aerosols with high-resolution time-of-flight aerosol mass spectrometry, Environ. Sci. Technol., 42, 4478-4485, doi:10.1021/Es703009q, 2008.

Alfarra, M. R., Prevot, A. S. H., Szidat, S., Sandradewi, J., Weimer, S., Lanz, V. A., Schreiber, D., Mohr, M., and Baltensperger, U.: Identification of the mass spectral signature of organic aerosols from wood burning emissions, Environ. Sci. Technol., 41, 57705777, doi:10.1021/Es062289b, 2007.

Blumenthal, D. L., White, W. H., and Smith, T. B.: Anatomy of a Los-Angeles Smog Episode - Pollutant Transport in Daytime Sea Breeze Regime, Atmos. Environ., 12, 893-907, 1978.

Chhabra, P. S., Ng, N. L., Canagaratna, M. R., Corrigan, A. L., Russell, L. M., Worsnop, D. R., Flagan, R. C., and Seinfeld, J. H.: Elemental composition and oxidation of chamber organic aerosol, Atmos. Chem. Phys. Discuss., 11, 10305-10342, doi:10.5194/acpd-11-10305-2011, 2011.

Davies, D. K., Ilavajhala, S., Wong, M. M., and Justice, C. O.: Fire information for resource management system: Archiving and distributing MODIS active fire data, IEEE T. Geosci. Remote, 47, 72-79, 2009.

Decesari, S., Fuzzi, S., Facchini, M. C., Mircea, M., Emblico, L., Cavalli, F., Maenhaut, W., Chi, X., Schkolnik, G., Falkovich, A., Rudich, Y., Claeys, M., Pashynska, V., Vas, G., Kourtchev, I., Vermeylen, R., Hoffer, A., Andreae, M. O., Tagliavini, E., Moretti, F., and Artaxo, P.: Characterization of the organic composition of aerosols from Rondnia, Brazil, during the LBASMOCC 2002 experiment and its representation through model compounds, Atmos. Chem. Phys., 6, 375-402, doi:10.5194/acp6-375-2006, 2006.

Docherty, K. S., Stone, E. A., Ulbrich, I. M., DeCarlo, P. F., Snyder, D. C., Schauer, J. J., Peltier, R. E., Weber, R. J., Murphy, S. M., Seinfeld, J. H., Eatough, D. J., Grover, B. D., and Jimenez, J. L.: Apportionment of primary and secondary organic aerosols in Southern California during the 2005 study of organic aerosols in riverside (SOAR), Environ. Sci. Technol., 42, 7655-7662, 2008.

Draxler, R. R. and Rolph, G. D.: HYSPLIT (HYbrid Single-Particle Lagrangian Integrated Trajectory) Model access via NOAA ARL READY Website (http://www.arl.noaa.gov/ready/hysplit4.html),
NOAA Air Resources Laboratory, Silver Spring (last access: August 2010), 2003.

Drewnick, F., Hings, S. S., DeCarlo, P., Jayne, J. T., Gonin, M., Fuhrer, K., Weimer, S., Jimenez, J. L., Demerjian, K. L., Borrmann, S., and Worsnop, D. R.: A new time-of-flight aerosol mass spectrometer (TOF-AMS) - Instrument description and first field deployment, Aerosol Sci. Tech., 39, 637-658, doi:10.1080/02786820500182040, 2005.

Duong, H. T., Sorooshian, A., Craven, J. S., Hersey, S. P., Metcalf, A. R., Zhang, X., Weber, R. J., Jonsson, H., Flagan, R. C., and Seinfeld, J. H.: Water-Soluble Organic Aerosol in the Los Angeles Basin and Outflow Regions: Airborne and Ground Measurements During the 2010 CalNex Field Campaign, J. Geophys. Res., in review, 2011.

Ervens, B. and Volkamer, R.: Glyoxal processing by aerosol multiphase chemistry: towards a kinetic modeling framework of secondary organic aerosol formation in aqueous particles, Atmos. Chem. Phys., 10, 8219-8244, doi:10.5194/acp-10-8219-2010, 2010.

Fuzzi, S., Decesari, S., Facchini, M. C., Cavalli, F., Emblico, L., Mircea, M., Andreae, M. O., Trebs, I., Hoffer, A., Guyon, P., Artaxo, P., Rizzo, L. V., Lara, L. L., Pauliquevis, T., Maenhaut, W., Raes, N., Chi, X. G., Mayol-Bracero, O. L., Soto-Garcia, L. L., Claeys, M., Kourtchev, I., Rissler, J., Swietlicki, E., Tagliavini, E., Schkolnik, G., Falkovich, A. H., Rudich, Y., Fisch, G., and Gatti, L. V.: Overview of the inorganic and organic composition of size-segregated aerosol in Rondonia, Brazil, from the biomass-burning period to the onset of the wet season, J. Geophys. Res., 112, D01201, doi:10.1029/2005jd006741, 2007.

Gao, S., Hegg, D. A., Hobbs, P. V., Kirchstetter, T. W., Magi, B. I., and Sadilek, M.: Water-soluble organic components in aerosols associated with savanna fires in southern Africa: Identification, evolution, and distribution, J. Geophys. Res., 108(D13), 8491, doi:10.1029/2002JD002324, 2003.

Graham, B., Mayol-Bracero, O. L., Guyon, P., Roberts, G. C., Decesari, S., Facchini, M. C., Artaxo, P., Maenhaut, W., Koll, P., and Andreae, M. O.: Water-soluble organic compounds in biomass burning aerosols over Amazonia - 1. Characterization by NMR and GC-MS, J. Geophys. Res., 107(D20), 8047, doi:10.1029/2001jd000336, 2002.

Grieshop, A. P., Logue, J. M., Donahue, N. M., and Robinson, A. L.: Laboratory investigation of photochemical oxidation of organic aerosol from wood fires 1: measurement and simulation of organic aerosol evolution, Atmos. Chem. Phys., 9, 1263-1277, doi:10.5194/acp-9-1263-2009, 2009.

Hennigan, C. J., Bergin, M. H., Dibb, J. E., and Weber, R. J.: Enhanced secondary organic aerosol formation due to water uptake by fine particles, Geophys. Res. Lett., 35, L18801, doi:10.1029/2008g1035046, 2008.

Hennigan, C. J., Bergin, M. H., Russell, A. G., Nenes, A., and Weber, R. J.: Gas/particle partitioning of water-soluble organic aerosol in Atlanta, Atmos. Chem. Phys., 9, 3613-3628, doi:10.5194/acp-9-3613-2009, 2009.

Hennigan, C. J., Sullivan, A. P., Collett Jr., J. L., and Robinson, A. L.: Levoglucosan stability in biomass burning particles exposed to hydroxyl radicals, Geophys. Res. Lett., 37, L09806, doi:10.1029/2010GL043088, 2010.

Hersey, S. P., Craven, J. S., Schilling, K. A., Metcalf, A. R., Sorooshian, A., Chan, M. N., Flagan, R. C., and Seinfeld, J. H.: 
The Pasadena Aerosol Characterization Observatory (PACO): chemical and physical analysis of the Western Los Angeles basin aerosol, Atmos. Chem. Phys., 11, 7417-7443, doi:10.5194/acp11-7417-2011, 2011.

Hughes, L. S., Allen, J. O., Bhave, P., Kleeman, M. J., Cass, G. R., Liu, D.-Y., Fergenson, D. P., Morrical, B. D., and Prather, K. A.: Evolution of atmospheric particles along trajectories crossing the Los Angeles Basin, Environ. Sci. Technol., 34, 3058-3068, 2000.

Husar, R. B., Patterson, D. E., Blumenthal, D. L., White, W. H., and Smith, T. B.: 3-dimensional distribution of air-pollutants in Los-Angeles Basin, J. Appl. Meteorol., 16, 1089-1096, 1977.

Jaffrezo, J.-L., Aymoz, G., Delaval, C., and Cozic, J.: Seasonal variations of the water soluble organic carbon mass fraction of aerosol in two valleys of the French Alps, Atmos. Chem. Phys., 5, 2809-2821, doi:10.5194/acp-5-2809-2005, 2005.

Justice, C. O., Giglio, L., Korontzi, S., Owens, J. Morisette, J. T., Roy, D., Descloitres, J., Alleaume, S., Petitcolin, F., and Kaufman, F.: The MODIS fire products, Remote Sens. Environ., 83, 244-262, 2002.

Kondo, Y., Miyazaki, Y., Takegawa, N., Miyakawa, T., Weber, R. J., Jimenez, J. L., Zhang, Q., and Worsnop, D. R.: Oxygenated and water-soluble organic aerosols in Tokyo, J. Geophys. Res., 112, D01203, doi:10.1029/2006jd007056, 2007.

Lee, S., Kim, H. K., Yan, B., Cobb, C. E., Hennigan, C., Nichols, S., Chamber, M., Edgerton, E. S., Jansen, J. J., Hu, Y. T., Zheng, M., Weber, R. J., and Russell, A. G.: Diagnosis of aged prescribed burning plumes impacting an urban area, Environ. Sci. Technol., 42, 1438-1444, doi:10.1021/Es7023059, 2008.

Lu, R. and Turco, R. P.: Air Pollutant Transport in a Coastal Environment .2. 3-Dimensional Simulations over Los-Angeles Basin, Atmos. Environ., 29, 1499-1518, 1995.

Mayol-Bracero, O. L., Guyon, P., Graham, B., Roberts, G., Andreae, M. O., Decesari, S., Facchini, M. C., Fuzzi, S., and Artaxo, P.: Water-soluble organic compounds in biomass burning aerosols over Amazonia - 2. Apportionment of the chemical composition and importance of the polyacidic fraction, J. Geophys. Res., 107(D20), 8091, doi:10.1029/2001jd000522, 2002.

McLafferty, F. W. and Turecek, F.: Interpretation of Mass Spectra, Fourth Edition, University Science Books, Mill Valley, California, 1993.

Miyazaki, Y., Kondo, Y., Takegawa, N., Komazaki, Y., Fukuda, M., Kawamura, K., Mochida, M., Okuzawa, K., and Weber, R. J.: Time-resolved measurements of water-soluble organic carbon in Tokyo, J. Geophys. Res., 111, D23206, doi:10.1029/2006jd007125, 2006.

Murphy, S. M., Agrawal, H., Sorooshian, A., Padro, L. T., Gates, H., Hersey, S., Welch, W. A., Jung, H., Miller, J. W., Cocker, D. R., Nenes, A., Jonsson, H. H., Flagan, R. C., and Seinfeld, J. H.: Comprehensive Simultaneous Shipboard and Airborne Characterization of Exhaust from a Modern Container Ship at Sea, Environ. Sci. Technol., 43, 4626-4640, doi:10.1021/Es802413j, 2009.

Ng, N. L., Canagaratna, M. R., Zhang, Q., Jimenez, J. L., Tian, J., Ulbrich, I. M., Kroll, J. H., Docherty, K. S., Chhabra, P. S., Bahreini, R., Murphy, S. M., Seinfeld, J. H., Hildebrandt, L., Donahue, N. M., DeCarlo, P. F., Lanz, V. A., Prévôt, A. S. H., Dinar, E., Rudich, Y., and Worsnop, D. R.: Organic aerosol components observed in Northern Hemispheric datasets from
Aerosol Mass Spectrometry, Atmos. Chem. Phys., 10, 46254641, doi:10.5194/acp-10-4625-2010, 2010.

Peltier, R. E., Weber, R. J., and Sullivan, A. P.: Investigating a liquid-based method for online organic carbon detection in atmospheric particles, Aerosol Sci. Tech., 41, 1117-1127, doi:10.1080/02786820701777465, 2007.

Phuleria, H. C., Fine, P. M., Zhu, Y. F., and Sioutas, C.: Air quality impacts of the October 2003 Southern California wildfires, J. Geophys. Res., 110, D07S20, doi:10.1029/2004jd004626, 2005.

Posfai, M., Simonics, R., Li, J., Hobbs, P. V., and Buseck, P. R.: Individual aerosol particles from biomass burning in southern Africa: 1. Composition and size distributions of carbonaceous particles, J. Geophys. Res., 108(D13), 8483, doi:10.1029/2002JD002291, 2003.

Reid, J. S., Koppmann, R., Eck, T. F., and Eleuterio, D. P.: A review of biomass burning emissions part II: intensive physical properties of biomass burning particles, Atmos. Chem. Phys., 5, 799825, doi:10.5194/acp-5-799-2005, 2005.

Robinson, A. L., Donahue, N. M., Shrivastava, M. K., Weitkamp, E. A., Sage, A. M., Grieshop, A. P., Lane, T. E., Pierce, J. R., and Pandis, S. N.: Rethinking organic aerosols: Semivolatile emissions and photochemical aging, Science, 315, 1259-1262, doi:10.1126/science.1133061, 2007.

Ruellan, S., Cachier, H., Gaudichet, A., Masclet, P., and Lacaux, J. P.: Airborne aerosols over central Africa during the experiment for regional sources and sinks of oxidants (EXPRESSO), J. Geophys. Res., 104, 30673-30690, 1999.

Sorooshian, A., Brechtel, F. J., Ma, Y. L., Weber, R. J., Corless, A., Flagan, R. C., and Seinfeld, J. H.: Modeling and characterization of a particle-into-liquid sampler (PILS), Aerosol Sci. Tech., 40, 396-409, doi:10.1080/02786820600632282, 2006.

Sorooshian, A., Murphy, S. M., Hersey, S., Bahreini, R., Jonsson, H., Flagan, R. C., and Seinfeld, J. H.: Constraining the contribution of organic acids and AMS $m / z 44$ to the organic aerosol budget: on the importance of meteorology, aerosol hygroscopicity, and region, Geophys. Res. Lett., 37, L21807, doi:10.1029/2010GL044951, 2010.

Sullivan, A. P. and Weber, R. J.: Chemical characterization of the ambient organic aerosol soluble in water: 1. Isolation of hydrophobic and hydrophilic fractions with a XAD-8 resin, J. Geophys. Res., 111, D05314, doi:10.1029/2005jd006485, 2006.

Sullivan, A. P., Weber, R. J., Clements, A. L., Turner, J. R., Bae, M. S., and Schauer, J. J.: A method for on-line measurement of water-soluble organic carbon in ambient aerosol particles: Results from an urban site, Geophys. Res. Lett., 31, L13105, doi:10.1029/2004g1019681, 2004.

Sullivan, A. P., Peltier, R. E., Brock, C. A., de Gouw, J. A., Holloway, J. S., Warneke, C., Wollny, A. G., and Weber, R. J.: Airborne measurements of carbonaceous aerosol soluble in water over northeastern United States: Method development and an investigation into water-soluble organic carbon sources, J. Geophys. Res., 111, D23S46, doi:10.1029/2006jd007072, 2006.

Timonen, H., Aurela, M., Carbone, S., Saarnio, K., Saarikoski, S., Mäkelä, T., Kulmala, M., Kerminen, V.-M., Worsnop, D. R., and Hillamo, R.: High time-resolution chemical characterization of the water-soluble fraction of ambient aerosols with PILS-TOC-IC and AMS, Atmos. Meas. Tech., 3, 1063-1074, doi:10.5194/amt-3-1063-2010, 2010.

Vutukuru, S., Griffin, R. J., and Dabdub, D.: Simulation and 
analysis of secondary organic aerosol dynamics in the South Coast Air Basin of California, J. Geophys. Res., 111, D10S12, doi:10.1029/2005jd006139, 2006.

Weber, R. J., Sullivan, A. P., Peltier, R. E., Russell, A., Yan, B., Zheng, M., de Gouw, J., Warneke, C., Brock, C., Holloway, J. S., Atlas, E. L., and Edgerton, E.: A study of secondary organic aerosol formation in the anthropogenicinfluenced southeastern United States, J. Geophys. Res., 112, D13302, doi:10.1029/2007jd008408, 2007.
Westerling, A. L., Hidalgo, H. G., Cayan, D. R., and Swetnam, T. W.: Warming and earlier spring increase western US forest wildfire activity, Science, 313, 940-943, doi:10.1126/science.1128834, 2006.

Zhang, Q., Alfarra, M. R., Worsnop, D. R., Allan, J. D., Coe, H., Canagaratna, M. R., and Jimenez, J. L.: Deconvolution and quantification of hydrocarbon-like and oxygenated organic aerosols based on aerosol mass spectrometry, Environ. Sci. Technol., 39, 4938-4952, doi:10.1021/Es0485681, 2005. 